\title{
Analysis of Marketing Strategy of Certified Rice Seeds (Case Study of Pt. Sang Hyang Seri (Persero) Regional Vi Business Unit Sidrap, South Sulawesi)
}

\author{
1Unggul Budi Kusuma, ${ }^{2}$ Jusni, ${ }^{3}$ Musran Munizu \\ 1Agribusiness Study Program, Graduate School, Hasanuddin University, Makassar, 90245, Indonesia \\ 2 Agribusiness Study Program, Graduate School, Hasanuddin University, Makassar, 90245, Indonesia \\ 3Agribusiness Study Program, Graduate School, Hasanuddin University, Makassar, 90245, Indonesia
}

Correspondence Author: ${ }^{1}$ Unggul Budi Kusuma, Agribusiness Study Program, Graduate School, Hasanuddin University, Makassar, 90245 , Indonesia E-mail: unggulbudikusuma@pasca.unhas.ac.id

Received date: 15 April 2019, Accepted date: 25 June 2019, Online date: 29 June 2019

Copyright: (c) 2019 Unggul Budi Kusuma et al., This is an open-access article distributed under the terms of the Creative Commons Attribution License, which permits unrestricted use, distribution, and reproduction in any medium, provided the original author and source are cre dited.

\begin{abstract}
This study aimed to analyze the marketing strategies that are appropriate and appropriate for PT. Sang Hyang Seri (Persero) VI Sidrap Regional Business Unit for the future. this research was conducted at PT. Sang Hyang Seri (Persero) Regional Business Unit VI Sidrap. This research was conducted in March-April 2019. The data used in this study are primary data and secondary data. Analysis of marketing strategy formulation using data processing methods based on SWOT analysis, SWOT analysis will show the position of PT. Sang Hyang Series VI Regional Business Unit Sidrap in its business environment. The results showed that the company's strategic position is in a strong position in utilizing its strength to deal with its internal weaknesses where the company's main strength is its extensive distribution network while its main weaknesses are lack of promotion of certified rice seed products and limited capital owned by the company. The results of the SWOT matrix analysis show that the marketing strategies that can be chosen by the company to be considered include increasing the sales promotion of certified rice seeds and prioritizing customer satisfaction while still paying attention to product quality. PT. Sang Hyang Seri (Persero) VI Sidrap Regional Business Unit is currently in position I, where the strategy that must be done by the company is to grow and build an intensive strategy or integration can be the most appropriate.
\end{abstract}

Keywords: SWOT Analysis, Certified Rice Seed, Marketing Strategy.

\section{INTRODUCTION}

The paradigm of agricultural development is the realization of a healthy and productive and creative society through resilient agriculture based on local resources [1]. Rice is the main food source of the population of Indonesia. In the field of national food security, rice (processed rice) is a strategic commodity that has a major contribution to the social, economic, political and safety aspects of the Indonesian nation. As the main food ingredient, rice has contributed more than 55\% to people's energy and protein consumption needs. One way to increase food production is to increase the harvest area [2]. The rapid growth of the human population underlies many environmental problems. Environmental problems cannot be solved, except for human population problems that can be addressed and that must be done with the number of people on planet Earth who support the environment to provide for their needs [3]. To make this happen, self-sufficiency in food is needed [4].

The need for rice increases every year and causes the need for rice seeds to also increase. In an effort to increase rice production, it is done by using superior certified seeds [5]. In presenting added value, he must emphasize the principle of efficiency to achieve the supply chain targets [6]. As well as promoting efficiency and synergy among partners, helping to achieve better environmental performance, minimizing the formation of deposits produces a resource economy, enhancing corporate image and positive exposition on the market [7].

To grow and to make a profit. One effort to increase rice production is through the use of certified superior varieties of seeds. In 2016 the Government of the Republic of Indonesia issued Minister of Agriculture Regulation Number: 036 / HK.150 / C 
/ 01/2016 concerning the Seed Independent Village Strengthening Technical Guidelines, which are part of the President of the Republic of Indonesia's Work Program policy as stipulated in the 2015 National Medium-Term Development Plan 2019. With the aim of stabilizing the 2015 Thousand Independent Village Seed Development activities specifically to support rice productivity [8].

Fulfillment of rice seed use in rice cultivation requires certified superior varieties of seed production. Certified seeds are the main feature in evaluating quality seeds. Based on Law Number 12 of 2012 and Minister of Agriculture Regulation Number 39 of 2006, it is stated that seeds on the market must be certified. Characteristics of certified seeds that already have data, the origin of the offspring are clear and can be seen on labels that are installed outside or inside the package of seeds [9].

PT. Sang Hyang Seri is one of the agricultural industry institutions which was originally in the form of a certified public company in 1971, perfected through PP No. 44 dated 28 November 1985. In 1995 the government changed the general company to PT Sang Hyang Seri (Persero) in the business of procuring and distributing certified rice seeds.

\section{Research Methode}

This research was conducted at PT. Sang Hyang Seri (Persero) Regional Business Unit VI Sidrap, South Sulawesi. This type of research is descriptive method research by carrying out case studies at PT. Sang Hyang Seri (Persero) Regional Business Unit VI Sidrap. The data used in this study are primary and secondary. In carrying out this research, data collection techniques carried out were: Observation or direct observation, Interview (interview), Documentation, Research questionnaire aimed at selected respondents such as General Managers, Marketing Managers, Assistant Marketing Managers and Marketing Supervisers.

Data processing in this study was carried out qualitatively and quantitatively which was then processed and analyzed using the SWOT analysis method. There are two stages of analysis, namely data collection, analysis phase, Data Collection Stages, namely the classification and pre-analysis stages. In this stage Internal Factor Evaluation (IFE) and the External Factor Evaluation (EFE) matrix are used. and internal-external matrix (IE). The analysis phase (process) at this stage all internal and external factors are utilized in the SWOT matrix model.

\section{Data Collection Stage (Input)}

\section{RESULT AND DISCUSSION}

The data collection stage is the identification of the factors associated in the analysis of marketing strategies for certified rice seeds at PT. Sang Hyang Seri (Persero) UBR VI Sidrap. These factors include internal factors, namely strengths (strengths) and weaknesses (weakness) as well as external factors, namely opportunities and threats.

Variable identification :

- Internal factors

The identification of the internal factors of PT. Sang Hyang Seri (Persero) Sidrap Regional Business Unit VI including its strengths and weaknesses will be described as follows:

a) Identification of Internal Factors - Strength

1. Research and development performance and product variants

2. Good cooperation with breeder farmers

3. The development of new superior varieties always innovates

4. Strict quality control from the production process to the final stage and seed certification by BPSB

5. Rice seed processing technology is available

6. Extensive distribution network

7. Producing high-quality rice seed products

b) Identification of Internal Factors - Weaknesses

1. Limited capital

2. Rice seeds cannot be stored for too long

3. Lack of promotion of certified rice seed products

4. Prospective rice seeds depend on production centers

- External Factors

The identification of external factors of PT. Sang Hyang Seri (Persero) Sidrap VI Regional Business Unit including opportunities and threats of the company, will be described as follows:

a. Identification of External Factors - Opportunities

1. Customer Loyalty

2. Market the government program

3. Farmers' interest in high certified rice seeds

4. Potential land area

b. Identification of External Factors - Threats

1. Climate change

2. Industrial competition in certified seeds

3. Generally farmers use rice seeds through their own production 
4. Pricing by the government that often changes

Giving Weight and Ranking

The internal and external factors that have been identified are evaluated using the matrix Internal Factor Evaluation (IFE) and the External Factor Evaluation (EFE) matrix.

\section{$>$ IFE Matrix}

The internal factor evaluation (IFE) matrix is used as an evaluation of the strengths and weaknesses that can be seen in Table 1.

Table 1. Internal Factor Evaluation Matrix - IFE

\begin{tabular}{|c|c|c|c|c|}
\hline & Internal Strategy Factors & & & \\
\hline \multicolumn{2}{|r|}{ Strength } & Weight & Rating & Total score \\
\hline 1 & $\begin{array}{l}\text { Research and development } \\
\text { performance and product variants }\end{array}$ & 0,10 & 4 & 0,4 \\
\hline 2 & $\begin{array}{l}\text { Good cooperation with breeder } \\
\text { farmers }\end{array}$ & 0,10 & 4 & 0,4 \\
\hline 3 & $\begin{array}{l}\text { The development of new superior } \\
\text { varieties always innovates }\end{array}$ & 0,10 & 4 & 0,4 \\
\hline 4 & $\begin{array}{l}\text { Strict quality control from the } \\
\text { production process to the final stage } \\
\text { and seed certification by BPSB }\end{array}$ & 0,11 & 4 & 0,44 \\
\hline 5 & $\begin{array}{l}\text { Rice seed processing technology is } \\
\text { available }\end{array}$ & 0,09 & 3 & 0,3 \\
\hline 6 & Extensive distribution network & 0,11 & 4 & 0,44 \\
\hline 7 & $\begin{array}{l}\text { Producing high-quality rice seed } \\
\text { products }\end{array}$ & 0,10 & 4 & 0,4 \\
\hline \multicolumn{5}{|c|}{ Weakness } \\
\hline 1 & Limited capital & 0,06 & 2 & 0,12 \\
\hline 2 & $\begin{array}{l}\text { Rice seeds cannot be stored for too } \\
\text { long }\end{array}$ & 0,07 & 3 & 0,21 \\
\hline 3 & $\begin{array}{l}\text { Lack of promotion of certified rice } \\
\text { seed products }\end{array}$ & 0,05 & 2 & 0,1 \\
\hline 4 & $\begin{array}{l}\text { Prospective rice seeds depend on } \\
\text { production centers }\end{array}$ & 0,10 & 4 & 0,4 \\
\hline \multicolumn{2}{|r|}{ Total } & 1,00 & & 3,61 \\
\hline
\end{tabular}

Source: Primary data that has been processed, 2019.

\section{EFE matrix}

The external factor evaluation (EFE) matrix is used as an evaluation of the opportunities and threats that can be seen in Table 2.

Table 2. External Factor Evaluation Matrix - EFE

\begin{tabular}{|c|c|c|c|c|}
\hline \multicolumn{2}{|r|}{ External Strategy Factors } & \multirow{2}{*}{ Weight } & \multirow{2}{*}{ Rating } & \multirow{2}{*}{ Total score } \\
\hline \multicolumn{2}{|c|}{ Opportunities } & & & \\
\hline 1 & Customer Loyalty & 0,10 & 2 & 0,2 \\
\hline 2 & Market the government program & 0,16 & 4 & 0,64 \\
\hline 3 & Farmers' interest in high certified rice seeds & 0,11 & 3 & 0,33 \\
\hline 4 & Potential land area & 0,15 & 4 & 0,6 \\
\hline \multicolumn{5}{|c|}{ Threats } \\
\hline 1 & Climate change & 0,09 & 2 & 0,18 \\
\hline 2 & Industrial competition in certified seeds & 0,16 & 4 & 0,64 \\
\hline 3 & $\begin{array}{l}\text { Generally farmers use rice seeds through their } \\
\text { own production }\end{array}$ & 0,10 & 3 & 0,3 \\
\hline 4 & Pricing by the government that often changes & 0,13 & 3 & 0,4 \\
\hline \multicolumn{2}{|r|}{ Total } & 1,00 & & 3,29 \\
\hline
\end{tabular}

Source: Primary data that has been processed, 2019.

Process Analysis

Factor analysis is the use of internal and external factors in quantitative models of strategy formulation. Analysis of these factors uses the SWOT matrix model, internal-external matrix (IE).

a. IE Matrix (Internal-External) 
The IE matrix is based on two key dimensions, namely the total score of the IFE matrix on the $\mathrm{x}$ axis and the total EFE matrix score on the y axis. IE Matrix can identify 9 cell strategies but in principle can be grouped into three main strategies, namely Growth strategy, Stability strategy, and Retrenchment strategy [10], the total weighted score for IFE and EFE is:

- Strong: $3.00-4.00$

- Average: $2.00-2.99$

- Weak: 1.00 - 1.99

Figure 1. IE Matrix of PT. Sang Hyang Seri (Persero) UBR VI Sidrap

Total IFE Value Given Weight

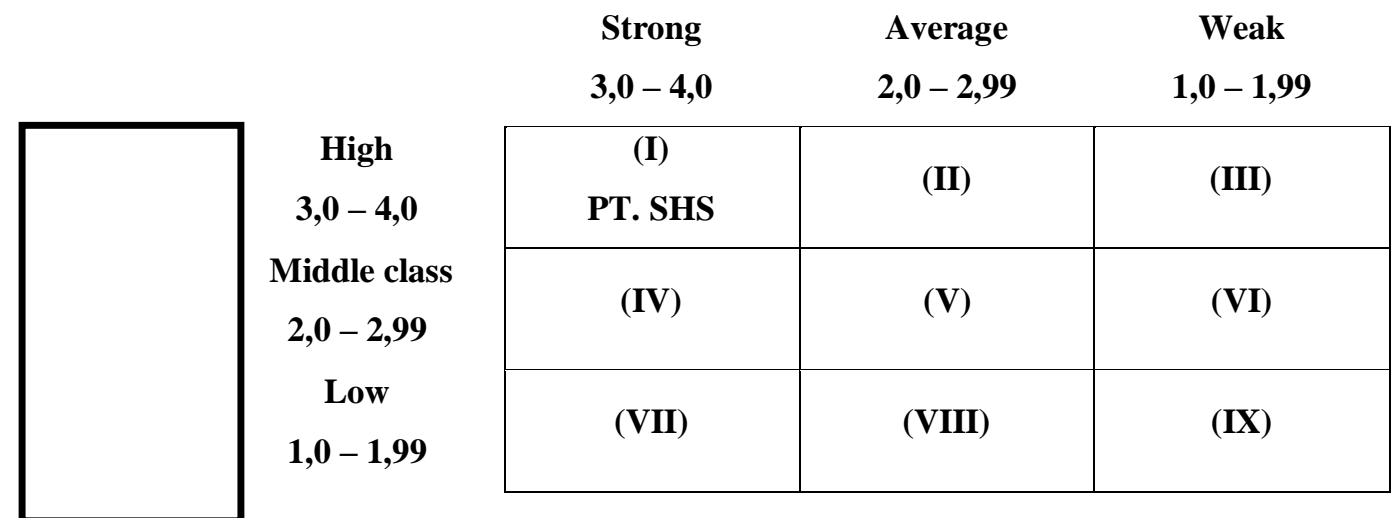

The results shown in the IE matrix where the $\mathrm{x}$ axis which is the input of the IFE matrix is 3.61, while the $\mathrm{y}$ axis which is the input of the EFE matrix is 3.29. Position of PT. Sang Hyang Seri (Persero) VI Sidrap Regional Business Unit is currently in cell I, where the strategy that must be carried out by the company is grow and build, intensive strategy or integration can be the most appropriate for these divisions. And appropriate risk measurement helps investors identify and choose investment options [11].

b. SWOT Matrix (Strengths-Weaknesses-Opportunities-Threats)

The SWOT Matrix (Strengths-Weakness-Opportunities-Threats) is used to formulate an alternative marketing strategy for PT. Sang Hyang Seri (Persero) UBR VI Sidrap, by combining internal and external factors resulting from the input stage (IFE and EFE matrix) which can be seen in Figure 2.

\begin{tabular}{|c|c|c|}
\hline External Analysis & $\begin{array}{l}\text { (Strengths) } \\
\text { 1. Research and development performance } \\
\text { and product variants } \\
\text { 2. Good cooperation with breeder farmers } \\
\text { 3. The development of new superior } \\
\text { varieties always innovates } \\
\text { 4. Strict quality control from the } \\
\text { production process to the final stage } \\
\text { and seed certification by BPSB } \\
\text { 5. Rice seed processing technology is } \\
\text { available } \\
\text { 6. Extensive distribution network } \\
\text { 7. Producing high-quality rice seed } \\
\text { products }\end{array}$ & $\begin{array}{l}\text { (Weakness) } \\
\text { 1. Limited capital } \\
\text { 2. Rice seeds cannot be stored for too } \\
\text { long } \\
\text { 3. Lack of promotion of certified rice } \\
\text { seed products } \\
\text { 4. Prospective rice seeds depend on } \\
\text { production centers }\end{array}$ \\
\hline $\begin{array}{l}\text { (Opportunities) } \\
\text { 1. Customer Loyalty } \\
\text { 2. Market the government } \\
\text { program } \\
\text { 3. Farmers' interest in high } \\
\text { certified rice seeds } \\
\text { 4. Potential land area }\end{array}$ & $\begin{array}{l}\text { Strategy S-O } \\
\text { 1. Improve quality and multiply certified } \\
\text { varieties of rice seeds (S1, S2, S3, S4, } \\
\text { S5, S7, O3, O4) } \\
\text { 2. Improve the performance and } \\
\text { capabilities of the company in } \\
\text { cooperation with breeder farmers and } \\
\text { related agencies in the process of } \\
\text { marketing certified rice seeds (S1, S2, } \\
\text { S3, S4, S5, S6, O2, O4) } \\
\text { 3. Conduct independent certification tests }\end{array}$ & $\begin{array}{l}\text { Strategy W-O } \\
\text { Optimizing rice seed production } \\
\text { capacity with available resources and } \\
\text { assistance from the government (W1, } \\
\mathrm{W} 2, \mathrm{~W} 3, \mathrm{~W} 4, \mathrm{O} 2, \mathrm{O} 4)\end{array}$ \\
\hline
\end{tabular}




\begin{tabular}{|c|c|c|}
\hline & at the company (S1, S3, S4, S7, O4) & \\
\hline $\begin{array}{l}\text { (Threats) } \\
\text { 1. Climate change } \\
\text { 2. Industrial competition in } \\
\text { certified seeds } \\
\text { 3. Generally farmers use rice } \\
\text { seeds through their own } \\
\text { production } \\
\text { 4. Pricing by the government that } \\
\text { often changes }\end{array}$ & $\begin{array}{l}\text { Strategy S-T } \\
\text { Improve the quality of products and } \\
\text { services to attract consumer interest (S1, } \\
\mathrm{S} 3, \mathrm{~S} 4, \mathrm{~S} 5, \mathrm{~S} 6, \mathrm{~S} 7, \mathrm{~T} 1, \mathrm{~T} 2, \mathrm{~T} 3, \mathrm{~T} 4)\end{array}$ & $\begin{array}{l}\text { Strategy W-T } \\
\text { Improve promotional programs } \\
\text { effectively and efficiently to maintain } \\
\text { existing customers and attract new } \\
\text { consumers (W1, W3, W4, T2, T3, T4) }\end{array}$ \\
\hline
\end{tabular}

Based on the results of the SWOT matrix analysis, it can be seen several marketing strategies that can be chosen by the company to be considered, including increasing the sales promotion of certified rice seeds and prioritizing customer satisfaction while paying attention to product quality. In addition, the company must also be able to expand a larger market share through more vigorous marketing efforts, by promoting and introducing certified rice seeds to consumers. The company also seeks to fulfill every consumer order in accordance with the volume of consumer demand.

\section{CONCLUSION}

The results of the analysis of internal and external identification of PT. Sang Hyang Seri (Persero) Regional Business Unit VI Sidrap, shows that the company's strategic position is in a strong position, IE Matrix analysis shows that the current position is in position I, where the strategy that the company must do is grow and build. Intensive or integrated strategy can be the most appropriate, in utilizing the strength it has to deal with its internal weaknesses where the company's main strength is its extensive distribution network while its main weaknesses are the lack of promotion of certified rice seed products and limited capital owned by the company. The SWOT matrix analysis shows that the marketing strategies that can be chosen by the company to be considered include increasing the sales promotion of certified rice seeds and prioritizing customer satisfaction while still paying attention to product quality.

\section{REFERENCES}

[1] Sirajuddin, S. N., Siregar, A. R., Nurlaelah, S., Lestari, V. S., \& Tenrisanna, V. (2017). The limitations and benefits of partnership sharing system of Corporated Cattle Market (CCM). American-Eurasian Journal of Sustainable Agriculture, 11(1), 11-15.

[2] Komala, D, R., N, Parining, I, W. Widyantara., 2019. Effectiveness of Irrigation Water Distribution System in Enhancing Rice Cropping Index at SubakPadanggalak, Kedewatan Irrigation Area, Bali /American-Eurasian Journal of Sustainable Agriculture. 13(2): 48-54.DOI: 10.22587/aejsa.2019.13.2.5.

[3] Yadollahi, Et al, 2014. Evaluation of Agricultural Management and Physical - Chemical Soil Characteristics on Diversification of Weed Species in Farms, Global journal of biodiversity science and management ISSN : 2074-0875.

[4] Prasekti. 2015. Economic Analysis of Ciherang Rice Seed Breeder Business (in Tamanan Kelurahan Tulungagung District, Tulungagung District) Agribusiness Journal Faculty of Agriculture Unita Vol. 11 No. 13

[5] Hanafi, Muhammad. 1998. Marketing Analysis at PT. Sang Hyang Series West Java Special Branch for Certified Rice Seed Products. Faculty of Agriculture. Bogor Agricultural Institute. Bogor.

[6] Sirajuddin, S. N., Mappangaja, A. R., Darma, R., \& Sudirman, I. (2015). Value added analysis of beef cattle supply chain actors micro-scale community farm-based. American-Eurasian Journal of Sustainable Agriculture, 9(7), 7-12.

[7] Quandt, O. (2014). Return policy of foodstuff in the retail as a strategic tool of sustainability in a small brazilian company. Australian Journal of Basic and Applied Sciences, 8(1), 460-468. [8] Direktorat Jenderal Tanaman Pangan. 2016. Technical Guidelines for Strengthening Seed Independent Villages for Fiscal Year 2016. Jakarta.

[9] Permentan. Regulation of the Minister of Agriculture. 2006. Regulation of the Minister of Agriculture Number 39 / Permentan / OT.140 / 8/2006. Use of Seed Source. Jakarta.

[10] Rangkuti, F. 2008. SWOT Analysis of the Technique for Dissecting Business Cases. PT Gramedia Pustaka Utama. Jakarta.

[11] Salehi, Et al, 2015. Review of Models to Measure Market Risk. Journal Of Biodiversity Science and Management ISSN : 2074-0875 2015 